\title{
Innovative Business Models and Initiatives Based on the Social and/or Ecological Mission
}

\author{
Justyna Szumniak-Samolej \\ Warsaw School of Economics, Warsaw, Poland
}

\begin{abstract}
This paper addresses innovative business models and initiatives functioning between business and social and/or ecological mission, which are actively and voluntarily engaged in implementing social and/or ecological changes. There are different opinions and ideas that coexist regarding this matter as well as its basic assumptions. The aim of this paper is to provide theoretical frameworks regarding the issues as well as to discuss the different opinions concerning the business models and enterprises. Additionally, three Polish examples of developing business activities according to the described model are presented. Results show that the key to creating and developing enterprises of this kind is innovation which allows social and ecological problems to be redefined as business challenges rather than threats and limitations, since they inspire creating new and revolutionary solutions. What is more, increasingly often enterprises based on the social and/or ecological mission cannot be characterised as traditional companies, because they do not have formal structures, hierarchy, or even employees. Their structures are hybrid or they are a result of new forms of organising human cooperation in the network economy. Therefore, the author defined them as "business models and initiatives". Moreover, the above trend is developing parallel to the "traditional" corporate social responsibility current. These initiatives are based on corporate social responsibility. Yet they are quite different from the traditional corporate social responsibility forms operating in the marketplace which are often misrepresenting this concept. The research methods used here provide an analysis of the most recent literature on the issues, referential research, and mini case studies.
\end{abstract}

Keywords: innovative business models, corporate social responsibility, sustainable business models, impact business models, social enterprise, hybrid structures

\section{Introduction}

At the beginning of the 21st century, the world continues to grapple with serious social and ecological problems. The social inequalities, poverty, unemployment, slavery, epidemics, political tensions, climate changes, natural catastrophes, water, and natural resources shortages - these are only some of the biggest global challenges. As well as other entities, the private sector plays an important role in grappling with these issues. Business, on one hand, is seen as one of the causes of the many social, ecological, and economic problems current in world. It is very common to believe that the companies thrive at the expense of people and natural environment. This belief is being reinforced by more and more economical scandals. If management is not

Justyna Szumniak-Samolej, Ph.D., assistant professor, Department of Management Theory, Warsaw School of Economics, Warsaw, Poland.

Correspondence concerning this article should be addressed to Justyna Szumniak-Samolej, Department of Management Theory, Warsaw School of Economics, al. Niepodległości 162, 02-554 Warszawa, Poland. 
coerced to do so, it fails to consider the social and ecological issues when making decisions. Management would prefer to treat the issues as an expense item, out of line with organizational commercial aims, rather than consider them as an opportunity for further development and competitive advantage. Yet, on the other hand, both large corporations and small companies, more and more often "enter the path of sustainability", undertaking various initiatives relating to corporate social responsibility. These operations are proactive and reactive, strategic, and occasional, incentivized by common benefits as well as the call of social duty. Eventually, they provide the society with smaller or bigger benefits. However, it is still not enough, as many compelling issues continue to remain unsolved.

Therefore, it has become more evident that the private sector should be engaged in the social and ecological issues more actively and in a more innovative way, since the companies have a greater potential of shaping their environment through their strategies, investments, and operations.

Creating new business models and initiatives led by the mission linking business, social, and environmental elements is one of the more active and innovative methods of getting involved in solving social and ecological issues. Although, it is not a new phenomenon, there are many initiatives of this kind currently appearing. The Goldman Sachs experts (2007) said that more and more capital is invested in creating and developing sustainable business models which the market handsomely rewards. This phenomenon has become global. Such initiatives are flourishing both in western developed markets and in emerging countries including Poland.

The aim of this paper is to provide theoretical frameworks regarding the issues as well as discuss the different opinions regarding the business models and initiatives. This can have a profound influence on the connection between business and social operations. This also includes an analysis of examples of such operations in the Polish market.

The research methods used here provide an analysis of both the most recent literature on the issues and also of the referential research and mini case studies. This paper, due to its limited volume, is only a preface to the issues presented which will be more broadly and deeply discussed in future papers.

\section{The Corporate Social Responsibility Concept}

The corporate social responsibility concept has been defined in many different ways, yet there is no agreement between theoreticians and practitioners which one is correct. One of the most popular corporate social responsibility definitions is the one included in the ISO 26000 norm (2010), according to which corporate social responsibility is defined as corporate responsibility for the influence of the organization's decisions for society and the environment following the business integrity which:

- brings sustainability including health and society welfare;

- considers stakeholders' expectations (persons or groups, being interested in organization's decisions and operations);

- follows the existing legislation and international norms of proceedings;

- is integrated within the organization's operations and implemented within the scope of its area of influence (Retrieved from http://www.pkn.pl/iso-26000).

The norm should be a "guide" to the corporate social responsibility. It has been created for all kinds of organizations, including business, administration, and the third sector (International Organization for Standardization, 2014). Although both the ISO 26000 norm and the entire corporate social responsibility framework are suitable for all organizational models, they are most popular among big companies and 
corporations, which include "corporate social responsibility programs" in their standard operations (Responsible Business Forum, 2015) or in the previous reports.

However, some implemented corporate social responsibility programs are often admonished (Szumniak-Samolej, 2013) and criticized that their goal is not to improve the environment, but solely to improve company image. Responsible Business Forum (2014) claimed that the dangerous phenomenon of the corporate social responsibility routinization has appeared lately — instead of focusing on evaluating and solving the most cogent and urgent problems of civilization, the creation of new editions of corporate social responsibility programs is the top priority. Elkington and Zeitz (2014, p. 38) claimed that the budgets for really important social responsibility operations are usually insufficient. The link between the corporate social responsibility strategy and the business strategy is not strong enough. Moreover, the potential of building decisive business models on the above basis is sorely missing.

Certainly "to generalize" is not recommended here, since there are many valuable operations as well as positive examples. Such conclusions are proposed by Wyszkowski (2014), for instance, on the basis of the Polish corporate social responsibility market observations. He claimed that people have a variety of good corporate social responsibility successful practices for the time being. Yet even if corporate social responsibility initiatives are not only the ways a company can enhance its image, but also improve its functioning within different kinds of company operations and are somehow effective regarding social or environmental benefits; they are not perceived as affecting monumental cultural change but only as additions to the standard business operations. Results seem to show that the corporate social responsibility concept will still be practiced and further develop, but perhaps become more and more formalized (this fact is indicated even by the European Parliament's directive dated April 2014, obligating the biggest companies to report non-financial data) rather than innovative and forward thinking.

Certainly the other side can acknowledge and bear witness that any of these initiatives are better than nothing at all. It is better if "the corporate social responsibility market is developing slowly and systematically" (Rok, 2013, p. 4), yet not shrinking. Despite many disadvantages, the corporate social responsibility practices show the necessity of taking the social and environmental issues into account in business practices. They also create a background for more decisive solutions.

Such decisive solutions are a second and parallel stream in the development of the corporate social responsibility concept, considering the social and environmental issues in firms' (and other organizations') operations, but are visibly different from the main, "traditional" corporate social responsibility stream. It is a designation not even called the corporate social responsibility, but based on the idea of the organization's social responsibility and willingness to undertake environmental, social, and business initiatives. In these types of enterprises, the social and environmental issues are seen as the source of opportunities and new possibilities (the market possibilities as well), not as limitations or expenses. These business models are built on social and/or environmental objectives. They also can be enterprises operating between business and social and/or ecological operations which follow the corporate social responsibility model more on an innovative basis than traditional.

\section{Business Models Built on the Social and/or Environmental Mission}

\section{Ideas Review-An Effort of the Theoretical Frameworks Determining}

Rok (2014a) claimed that "the third corporate social responsibility wave is coming"-CSR 3.0, which is based on the interaction and cooperation not only among institutions but also people. Maybe in that third wave, 
people should eliminate the corporate social responsibility term and leave it as an internal characteristic. It is time to focus on how the shared social, economic, etc. area is built.

Kotler, Kartajaya, and Setiawan (2010) shared this opinion and claimed that the "era of values" is coming. Its main feature is that more and more people are trying to find the solution to their concerns - the solution which will change the world for the better. Therefore, they are searching for companies which in their mission, vision, and values express the aims meeting their need for social, economic, and environmental justice. The companies are still trying to meet the clients' needs, yet advance one level higher by interacting with them. They gained the competitive advantage following their values and their goal. Besides achieving profit, they attempted to address social problems with solutions.

Hurst (2014) followed the same idea and claimed that the birth of The Purpose Economy is observed defined by the "quest for people to have more purpose in their lives" (p. 250). He stated that "purpose" is one of the basic human needs. Yet the previous stages of economic development ignored this need. The purpose economy is based on the company creating values, allowing both the employees and clients to attain important goals (private, supporting internal development as well as building relationships in society and bonds with other people). Purpose of driven companies concentrates not only on making profit, but also on the positive influence on the people and the planet. Therefore, a challenge for business is market development focusing on the people and their needs. Thus they need creativity, innovation, and an entrepreneurial spirit.

Also Porter and Kramer (2011) wrote about the need of innovation and changing the companies' attitude in regard to social and environmental problems. They claimed that the firms have to learn how to foster and create a positive relationship between market success and the social progress. Therefore, they proposed a formula of creating shared value, based on producing economic value in a way which creates social value as well as by addressing the social problems. They stated that redefining the goal of a company in a way to generate not only profit but also to foster social-economic values will create a new wave of innovations and productivity growth in the economy. It will also change the image of capitalism.

The description of business and corporate social responsibility described above are especially about the firms (mostly new), which the social and environmental mission have in their DNA. These firms take into consideration in their business model not only the need to achieve profit, but simultaneously to achieve social and/or ecological goals. Yet neither in theory nor in practice are there any unambiguous models and definitions for these types of firms (Schaltegger, Lüdeke-Freund, \& Hansen, 2012; Boons \& Lüdeke-Freund, 2013; Bocken, Short, Rana, \& Evans, 2014). Therefore, they have different names, i.e., sustainable business models (Bocken et al., 2014), the companies for sustainable development (Rok, 2014b), impact business models (B Lab, 2013), triple bottom line business models (Osterwalder \& Pigneur, 2012), B corps. (Honeyman, 2014), or for-benefit enterprise (Sabeti, 2011).

\section{The Meaning of Innovations in Sustainable Business Models}

Regardless the name, size, business profile, legal status, or the markets in which they operate, these firms have one common, very important feature-innovation (Boons \& Lüdeke-Freund, 2013; Bocken et al., 2014). Bocken et al. (2014) defined it as,

Innovations that create significant positive and/or significantly reduced negative impacts for the environment and/or society, through changes in the way the organization and its value-network create, deliver value, and capture value (i.e., create economic value) or change their value propositions. (p. 44) 
Innovation is the key to creating and developing these kinds of business models, as it allows quitting the former paradigm, that is, the traditional corporate social responsibility view and the traditional role business plays in society. It fosters addressing social and ecological issues not as limitations, but business challenges inspiring the creation of new and revolutionary solutions. As Honeyman (2014) claimed,

These companies are a part of a dynamic and exciting movement to redefine success in business by using their innovation, speed, and capacity for growth not only to make money but also to help alleviate poverty, build stronger communities, restore the environment, and inspire us to work for a higher purpose. (p. 1)

These firms introduce new narratives, new expectations, and new innovations to achieve more than profits. The aim of this movement is to create positive, innovative, and practical solutions to global problems. This movement is for something and not against anything (Honeyman, 2014).

\section{The Chosen Market Initiatives Supporting Creating Innovative, Sustainable Business Models}

Building business on a social and/or environmental mission basis is not a radically new idea. These types of businesses were already springing up many years ago, Body Shop and Ben \& Jerry's are just two examples. Nevertheless nowadays, this phenomenon is becoming more and more popular and its scope is bigger and bigger. There are also many different initiatives appearing, even some institutional and legal, supporting building such kind of enterprises. One of such solutions nurturing the creation of sustainable business models is Benefit Corporation - a new legal form for firms driven by the social and/or environmental mission operating in the US (Clark et al., 2013).

A "B Corp" is a very interesting initiative as well. It is a certification system for all companies worldwide which are voluntarily following the requirements regarding the effectiveness of social and environmental operations as well as transparency (B Lab, 2014). Yet "B Corp" is not only a certification system, but also a movement to create firms that operate on a business mission basis, while simultaneously attempting to provide a positive impact on society and the natural environment. This mission is also supported by a well-tailored structure that provides for self-evaluation and solutions where needed, building transparency, and eventually making the mission and the implemented practices more credible (Elkington \& Zeitz, 2014).

Another enterprise supporting creative innovative and sustainable business model is "plan B for business". Created by "the B team"- a group of the world's business leaders established by R. Bransona and J. Zeitz: It works toward a future in which the purpose of business is to be a driving force for social, environmental, and economic benefit and change (Elkington \& Zeitz, 2014). The team thinks that the "plan A paradigm" by which companies are driven purely by profit motive is no longer viable. There is a crying need to develop long-term and decisive solutions which foster the development of opportunities for more equitable and sustainable economy. They stated that business leaders following this path have to undertake four obligations:

- reduce harm to the planet and support its restoration;

- treat the well-being of people as a priority;

- ensure good governance and transparency;

- initiate cooperation between different sectors to accelerate better business models implementation.

\section{The Organization Structures and Legal Forms of Sustainable Business Models in the Network Economy}

It has to be emphasized that the business models described here are the enterprises whose paradigm lies somewhere between business and social operations. Therefore, often they can hardly be clearly classified to any one specific category or legal form. 
Moreover, in the era of the network economy, the rise of such companies is driven by common-based peer production or the collaborative economy based on the development of network communication technologies. The diffusion and development of these technologies support the appearance of new non-formalized and non-hierarchical models of organizing people's activity and new social structures (i.e., virtual communities), which eventually leads to the deinstitutionalization and wide spread dissemination of new mechanisms of cooperation (i.e., crowdfunding and sharing economy).

Therefore, the proper term for such kinds of operations, in the author's opinion, is endeavors or initiatives. They do not have to have formal structures, hierarchy, offer incentives to operate, be effective, or engage participants. The author defined them as "innovative business models and initiatives based on social and/or ecological mission".

Sabeti (2011), among others, talked about the need to create those new types of hybrid organizational structures. He claimed that a new era is coming where borders are blurred. The commercial business entities are engaged in social and environmental activities, while non-governmental organizations are developing sustainable business models. There are new business models being developed every day as well as a new type of businessman driven by a social mission. Sabeti (2011) also stated that there is no longer a need to differentiate between "non-profit" and "for-profit", based on the primary feature of both initiatives. The same holds true regarding, "for benefit". Sabeti (2011) also claimed that as these types of structures become more and more common, the fourth sector of the economy will be emerging. This sector will cooperate with public administration, the business area, and non-governmental organizations. Yet it will be a separate scope of operations. Sabeti (2011) was even convinced that this sector's development will shape the development of all of capitalism.

Elkington and Zeitz (2014) shared this opinion. They claimed that business is nowadays facing a "breakthrough challenge", following the necessity to create "a shared vision of a radically better future and to work out new ways to measure and incentivize progress" (p. 2). They stated that a new paradigm of creating and developing business is needed to make the effective implementation of strategies and business models in positive response to the "breakthrough challenge". Creating new forms of human activity is indispensable to attain these aims, since the dominating organizational and ownership structures are not flexible, innovative, nor dynamic enough to ensure long-term sustainable development. These new structures have to stimulate entrepreneurship and innovation, while at the same time, take the needs of important groups of stakeholders into consideration.

\section{Polish Examples of Initiatives Based on the Social and/or Environmental Mission}

Three case studies of the initiatives based on the social and/or environmental mission will be described in this part of the paper. All come from the clothing industry and are new enterprises following broadly understood cooperation with different stakeholders groups. Therefore, their organizational frameworks are "blurred". In all the cases described, Internet technologies especially the social media play a very important role in the communication with stakeholders.

\section{NotJustShop}

It is a micro firm established in 2011. It produces and sells clothing for men and women. Its competitive advantage over other neophyte clothing companies in Poland is the manner in which the firm's mission is 
successfully implemented in everyday operations. The company's mission claims "to make the world a better place". It is a major goal and the company believes that it does not have to rely on huge projects and budgets to meet the goal. "It all begins with small gestures, showing someone that something is possible... We want to show you... that everything is possible" (Retrieved from http://notjustshop.com/pl/content/4-o-nas). How is this mission fulfilled in practice? Its roots are deep in the idea of the company's business model. Here are a few key elements:

- organizing aid actions;

- getting consumers involved;

- raising funds;

- offering consumer oriented products;

- getting beneficiaries involved;

- promoting transparency and open communication.

Firstly, "NotJustShop" is very actively involved in initiating and promoting aid actions which are the driving force of the company's operations. The company supports mainly children and families living in the vicinity of the firm's operations. The idea of getting the consumers involved as well as raising funds is very interesting. While purchasing anything in the Internet shop, besides the product's description, price, and photos, the client can review in depth what portion of the price is allocated for the social fund. It is usually $10 \%$ of the price, but can be as high as $25 \%$. The consumer may also donate any additional sum for a select charity project.

Obviously promoting charity is not enough to encourage the clients to buy the product. Firstly, these products are of a very high quality made in Poland from Polish materials. Young people who want to differentiate and emphasize their individualism comprise the target market. There is also one more aspect creating added value. Some products are designed during workshops together with the project's beneficiaries, for example, a workshop where children create artwork which can be embedded on T-shirts and blouses. These workshops are also very important in terms of their social role-for children they are a gateway from everyday life. They also make them feel that they can create something valuable - a real product. As the founder of the company claims, it is very important to teach both the kids and their parents that the aid is not a given but money should be earned from valued work. The participants can easily identify with the projects in which they have exercised their imagination to create items of personal satisfaction as well as material value (Krukowska, 2014a). The process of creating such a product is always conducted as a whole project with its own name on the website accompanied by a short video presentation.

It is also noteworthy that some of the clothing designed by children's parents, supported by the company or consumers, can be entered in the contests organized on Facebook. Getting consumers involved and rallying the community around the brand are the next important aspects of building the brand image and creating its uniqueness. As it appears on the company's website: "It is not just a shop... It is a great power, it is a movement. It is an action changing the world and people" (Retrieved from http://notjustshop.com/pl/content/4-o-nas). "It is a style of life, a way to show to other people and the whole world that we can change our environment" (Retrieved from http://notjustshop.com). It is possible then that the company's objective is to create a social movement around its values and actions. It is not a new concept. Social support in such business models is crucial. It may be the only way the company can create the social value included in its mission. Another example of such a social movement supporting social objectives, which are already global, was created around the brand TOMS (Bachnik \& Szumniak-Samolej, 2013). "NotJustShop" 
is thus initiating additional efforts, not connected with the product actions, which aim to build and involve the community (i.e., organizing a series of meetings for students regarding "the ways of changing the world" or of collecting electro trash). Nowadays social media is a very useful tool for rallying the community around the brand. "NotJustShop" recognized this fact and actively utilized the potential of such portals as Facebook, YouTube, Twitter, Pinterest, or Instagram to post movies, company news, and involve the stakeholders in the communication process or collaborative creation of the product's promotion.

Company representatives emphasized that the company is not a foundation, but a typical business company driven by both business objectives and social goals. They said that they use their business abilities to make the world a better place (PolakPotrafi.pl, 2014). They also claimed that currently things are not that easy in Poland. The company's owner said that to make any profits, he would have to sell a few hundred pieces a month and currently he is selling only one hundred maximum (Krukowska, 2014a). He claimed that Polish consumers still associate the charity operations with non-governmental organizations or the street fund raising. They do not believe that business operations also encourage organizing effective support (Krukowska, 2014a). He lamented that in some months, sales in the US are better than that in Poland.

Regarding profile of "NotJustShop" and its ideas for expanding in the marketplace the role of its founder cannot be ignored. His personal involvement and passion, as well as his energy and drive to action to overcome obstacles make the company's values sincere and authentic. This attitude encourages the belief in his intentions to join "the movement".

\section{Wisłaki}

It is a socially responsible fashion project and the first ecological clothing brand in Poland which has been established as a crowdfunding project. As the brand creators claimed, the project Wisłaki supports an ecological lifestyle whose definition lies somewhere among ecology, fashion, environmental protection, and funny animals from the Vistula River (Wisłaki, 2015a). This is the way the creators wish to describe the alternative for the mass production of clothing.

The launch of Wisłaki clothing took place in December 2014. It markets clothing for adults and children made of GOTS - organic cotton. The brand's style is based on monochromatic white and black colors which highlight the brands "added value". The clothing design features protected animals living in the vicinity of the Vistula River. Besides the ecological cotton and protected animals, another ecological message is financial support, in cooperation with the Polish Society of Birds Protection, established for the protection program of endangered animal species.

It is very interesting that the Wisłaki collection was not created as a product of a formal company, but in broad cooperation. At the beginning, it was a sharing among the product's originators. Cooperation between sponsors and partners, like the Polish Society of Birds Protection, restaurants, media, firms, and cultural institutions was the next stage. The partner organizations designated prizes for people supporting the crowdfunding project, which was the next very important stage in the cooperation involved in creating the brand. A fund raising event for the crowdfunding was held in September 2014 on the website (mintu.me platform) with a goal 20,000 PLN. The organization exceeded the goal raising 20,935 PLN. The project was supported by 145 persons (Retrieved from https://mintu.me/projects/cf/moda/257/wislaki/). The community supported the brand on Facebook with regards to the clothes design. Consulting was the next step (Wisłaki, 2015b). 
The Wisłaki creators' objective was not only to produce and market its clothing collection, but also to highlight the ecological life style. Therefore, the project included initiatives promoting the ecology concept in fashion and sharing its knowledge about crowdfunding and the ecosystem of the Vistula River. The crowdfunding workshops, meetings regarding the animals living in the vicinity of the river, and walks tracing them were successful (Krukowska, 2014b).

As already mentioned, Wisłaki is a very young brand. It will be very interesting to watch its future development.

\section{Nurture the World}

"Nurture the World" is a strict business organization driven by profits as well as activities supporting social need similar to "NotJustShop" described earlier. The company was established with the objective of making and selling clothing and accessories with a portion of the profits donated to different organizations that are effectively working to end child hunger.

The company was established in 2013 by a Polish woman living in the US. Before she even started business operations, she was interested in the problem of child hunger. In 2012, together with her friend, she established "the World Nurture Foundation", dedicated to addressing this problem. From the beginning, the foundation cooperated with UN and its World Food Program (WFP). Since garnishing outside financial support became more difficult than anticipated, it became her inspiration to found a company which in addition to its business objectives also focused on social needs, such as addressing the problem of child hunger worldwide (Krukowska, 2014a).

The company's mission is "making and selling quality products that nurture the world" (Retrieved from http://www.nurturetheworld.com). Its mission is being implemented and integrated into practical operations by focusing on cause of related marketing. This means that a portion of sales revenue is donated to different organizations that are working to end child hunger. "Nurture the World" still cooperates with "the World Nurture Foundation" as well as "the World Food Program", yet it also supports different local organizations (Food Bank for New York City in the USA, Acao da Cidadania in Brazil, and the Polish Red Cross).

The bases of the firm's operations are:

- selling good products (good quality and ecological);

- nurturing hungry children (by donating a part of the sales profits);

- supporting local communities (i.e., local firms manufacturing "Nurture the World" products);

- promoting local products and brands (by partnership with local brands and designers);

- supporting local economies (the products are being manufactured in countries, where the company operates in the US, Brazil, and Poland) (Retrieved from http://www.nurturetheworld.com).

The company's first product was an eco-friendly cotton bag Share the Love With Children created in partnership with the World Food Program. A portion of the profits from the sale of the bags were allocated to provide meals for children in Malawi. The firm's portfolio is now larger, yet the assortment itself is still limited. Cotton bags are still the primary product offered in four versions: classic bag (buying this bag the customer provides 50 meals for children in Malawi, in support of WFP), nurture BR5 (provides funds for five meals for children in Brazil), nurture USA bag (provides funds for five meals for children in the USA), and nurture PL5 (provides funds for five meals for children in Poland) (Retrieved from http://www.nurturetheworld.com). 
Besides bags, the company's portfolio includes lady's apparel and accessories, all of which are marketed in the US, Brazil, and Poland.

Yet "Nurture the World" is also an international project based on alliances with global and local support foundations as well as different firms, consumers, celebrities, designers, sportsmen, journalists, diplomats, and artists.

There are different forms of cooperation with the company which support missions of "Nurture the World":

- The individuals help by buying the products;

- The companies help selling or designing the products;

- Corporations may be involved in CSR cooperation;

- Any firm or corporation may order a product custom designed for them;

- Celebrities promote the brand and the mission (Retrieved from http://www.nurturetheworld.com).

Besides manufacturing and selling its products, "Nurture the World" organized different events like concerts or conferences. As stated by the founder of the company, the mission of the firm includes connecting people all over the world (Krukowska, 2014a).

\section{Conclusions}

Branson (2014) convinced that "in a long run, only those business enterprises will survive which offer benefits both for people and the planet. We can all take advantage of the development of sustainable business models". This sentence points out the ever growing trend of establishing and developing innovative forms of organizations connecting commercial and social and/or ecological objectives. There are just a few initiatives of this type so far, yet in the coming years, there will probably be more and more such decisive ideas, businesses, leaders, and sectors (Elkington \& Zeitz, 2014).

This paper tries to establish an overall theoretical framework as well as compare different ideas for business models, existing between a business and social mission, which are actively and voluntarily engaged in implementing social and/or ecological changes. It was also attempted to show here that increasingly often these business models can rarely be characterized as traditional companies, because their structures are hybrid, or they are new forms of organizing human cooperation in the network economy. It was also shown that the development of this trend is parallel to the "traditional" corporate social responsibility stream adapted in the firms. These initiatives are based on business social responsibility. Yet they are quite different from the extremely traditional forms operating in the marketplace, formalizing and often even misrepresenting this concept. It was also emphasized that the key to creating and developing these types of business models is innovation which allows social and ecological problems to be redefined as business challenges rather than threats and limitations which inspire creating new, revolutionary solutions. There are a few Polish examples following the described business model presented at the end of this paper. The examples described can be categorized as innovative businesses or enterprises, which cannot be viewed as traditional companies, because they are products of new forms of organizing cooperation between people in the network economy. Their operations show that the idea of business social responsibility has the potential of building new creative solutions beneficial to all the parties involved.

In the author's opinion, this subject will stimulate a field of fascinating research in the coming years. It will explore interesting phenomena and problems worth learning and researching in depth, such as: 
- How the ideas presented in this paper develop?

- How these kinds of enterprises can be defined and what are their frameworks?

- What are the types of difficulties they face and what are the solutions?

- How these types of projects should be managed and what is the role of the leader?

- Are these enterprises able to create a real economic as well as social and/or ecological value? How this value can be measured?

- Can the social/ecological mission remain the same and maintain its importance while the operation is developing?

- How frequently will new enterprises appear in this area?

- What is the consumers' and other stakeholders' response to these initiatives?

- What is and will be the role of network technologies in this process?

- Is there a long-term change in the attitude towards business operations or is it just a short-term trend?

Showing the sources and areas of changes as well as searching for answers for the above questions is very intriguing and inspiring issues for theoreticians. Yet they also encouraged practitioners to take an active and creative part in the processes described. It is even more important regarding the fact that nowadays network technologies as well as new forms of cooperation among people give everyone a chance to initiate a very important project. ${ }^{1}$

\section{References}

B Lab. (2013). An evolution impact measurement. Retrieved from http://www.bcorporation.net/blog/an-evolution-in-impact-measurement

B Lab. (2014). Why B Corps matter. Retrieved from http://www.bcorporation.net/what-are-b-corps/why-b-corps-matter

Bachnik, K., \& Szumniak-Samolej, J. (2013). Shared value in practice: TOMS business model. Chinese Business Review, 12(9), 639-645.

Bocken, N. M. P., Short, S. W., Rana, P., \& Evans, S. (2014). A literature and practice review to develop sustainable business model archetypes. Journal of Cleaner Production, 65, 42-56.

Boons, F., \& Lüdeke-Freund, F. (2013). Business models for sustainable innovation: State of the art and steps towards a research agenda. Journal of Cleaner Production, 45, 9-19.

Branson, R. (2014). Like a virgin. Secrets they won't teach you at business school. Warsaw: Studio Emka.

Clark, W. H., Vranka, L., Berick, J., Merritt, K., Montgomery, J., Sheehan, P. W., ... Storper, J. S. (2013). The need and rationale for the benefit corporation: Why it is the legal form that best addresses the needs of social entrepreneurs, investors, and, ultimately, the public. Retrieved from http://benefitcorp.net/storage/documents/Benecit_Corporation_White_Paper_1_18_2013.pdf

Elkington, J., \& Zeitz, J. (2014). The breakthrough challenge. San Francisco: Jossey-Bass.

Goldman Sachs. (2007). Goldman Sachs report (June 22). Retrieved from http://www.natcapsolutions.org/business-case/GoldmanSachsReport_v2007.pdf

Honeyman, R. (2014). The B Corp handbook. San Francisco: Berrett-Koehler Publishers.

Hurst, A. (2014). The purpose economy. Boise: Elevate.

International Organization for Standardization. (2014). ISO 26000-Social responsibility. Retrieved from http://www.iso.org/iso/home/standards/iso26000

Kotler, P., Kartajaya, H., \& Setiawan, I. (2010). Marketing 3.0. Warsaw: MT Biznes.

Krukowska, M. (2014a). Good will businessmen. $\quad$ Retrieved from http://csr.forbes.pl/przedsiebiorcy-dobrej-woli,artykuly, 178809,1,2.html

Krukowska, M. (2014b). Crowdfunding in deserving cause. Retrieved from http://csr.forbes.pl/projekty-eko-crowdfundingowe,artykuly,183080,1,2.html

${ }^{1}$ For instance in the US, an eight-year-old girl established a social enterprise called "Make a Stand". 
Mintu.me. (2015). Wistaki. Retrieved from https://mintu.me/projects/cf/moda/257/wislaki/

National Standards Body in Poland. (2014). ISO 26000. Retrieved from http://www.pkn.pl/iso-26000

NotJustShop. (2014a). About us. Retrieved from http://notjustshop.com/pl/content/4-o-nas

NotJustShop. (2014b). Home page. Retrieved from http://notjustshop.com

Nurture the World. (2014). Home page. Retrieved from http://www.nurturetheworld.com

Osterwalder, A., \& Pigneur, Y. (2012). Business model generation. Gliwice: Helion.

PolakPotrafi.pl. (2014). NotJustShop. Retrieved from http://polakpotrafi.pl/projekt/notjustshop

Porter, M. E., \& Kramer, M. R. (2011). Creating shared value. Harvard Business Review, 89, 1-17.

Responsible Business Forum. (2014). CSR 2014 trends. Retrieved from http://odpowiedzialnybiznes.pl/wp-content/uploads/2014/03/Trendy-CSR-2014.pdf

Responsible Business Forum. (2015). The report responsible business in Poland. Good practices 2014. Retrieved from http://odpowiedzialnybiznes.pl/wp-content/uploads/2015/04/Raport-Odpowiedzialny-biznes-w-Polsce-2014.-Dobre-praktyki _Forum_Odpowiedzialnego_Biznesu.pdf

Rok, B. (2013). Catastrophic vision. The report on the responsible business in Poland. Retrieved from http://odpowiedzialnybiznes.pl/wp-content/uploads/2014/04/Raport_Odpowiedzialny_biznes_w_Polsce2013.Dobre_Praktyki .pdf

Rok, B. (2014a). Towards CSR 3.0-Debate. Retrieved from http://odpowiedzialnybiznes.pl/artykuly/w-kierunku-csr-3-0-debata

Rok, B. (2014b). CSR this year (Responsible Business, CSR compendium, No. 12, June).

Sabeti, H. (2011). The for-benefit enterprise. Harvard Business Review, 89(11), 98-104.

Schaltegger, S., Lüdeke-Freund, F., \& Hansen, E. G. (2012). Business cases for sustainability: The role of business model innovation for corporate sustainability. International Journal of Innovation and Sustainable Development, 6(2), 95-119.

Szumniak-Samolej, J. (2013). Responsible business in the network economy. Warsaw: Poltext.

Wisłaki. (2015a). Home page. Retrieved from http://www.wislaki.com/english.php

Wisłaki. (2015b). Facebook. Retrieved from https://www.facebook.com/wislaki/info?ref=page_internal

Wyszkowski, K. (2014). Towards CSR 3.0-Debate. $\quad$ Retrieved from http://odpowiedzialnybiznes.pl/artykuly/w-kierunku-csr-3-0-debata 